\title{
Analisis Video Views To Likes Ratio Tiktok Artis Dengan Followers Terbanyak Di Indonesia
}

\author{
I Gede Agus Martana Putra \\ agus.martana4@gmail.com
}

\begin{abstract}
TikTok is a social media application launched by a Chinese company. TikTok allows users to create 15-second videos accompanied by music, filters, and several other creative features. In Indonesia, there are 30.7 million active users, making Indonesia the country with the largest TikTok users in the world. The large number of active TikTok users in Indonesia can certainly provide an opportunity for brands to make the TikTok platform a social media marketing platform. The 5 artists with the most followers in Indonesia who use TikTok as an entertainment platform are: Sandys.ss, Cahyanirynn, RiaRicis, JharnaBhagwani, and Saalhaerid. The purpose of this study is to calculate the credibility of the TikTok account performance of 5 artists with the most followers in Indonesia. The method used for this research is quantitative exploratory method. The results of this study indicate that the saalhaerid tiktok account gets the first rank and has the most followers.
\end{abstract}




\section{ABSTRAK}

TikTok merupakan aplikasi sosial media yang diluncurkan oleh perusahaan asal Tiongkok. TikTok memungkinkan penggunanya membuat video berdurasi 15 detik yang disertai dengan musik, filter, dan beberapa fitur kreatif lainnya. Di Indonesia terdapat 30,7 juta pengguna yang aktif sehingga menjadikan Indonesia sebagai negara dengan pengguna TikTok terbesar di dunia. Maraknya jumlah pengguna TikTok yang aktif di Indonesia tentu dapat memberikan peluang bagi brand untuk menjadikan platform TikTok sebagai platform social media marketing. Adapun 5 artis dengan followers terbanyak di Indonesia yang memanfaatkan TikTok sebagai platform dunia hiburan, yaitu artis : Sandys.ss, Cahyanirynn, RiaRicis, JharnaBhagwani, dan Saalhaerid. Tujuan dari penelitian ini yaitu untuk menghitung kredibilitas dari performa akun TikTok 5 artis dengan followers terbanyak di Indonesia. Metode yang digunakan untuk penelitian ini yaitu metode eksploratif kuantitatif. Hasil dari penelitian ini menunjukan bahwa Account tiktok saalhaerid mendapatkan peringkat pertama dan memiliki followers terbanyak. 


\section{Pendahuluan}

Kemajuan Teknologi Informasi dan Komunikasi (TIK) dan pemanfaatannya

dalam berbagai bidang kehidupan menandai perubahan peradaban manusia menuju masyarakat informasi. Internet adalah produk Teknologi Informasi dan Komunikasi (TIK) yang memudahkan setiap orang memperoleh dan menyebarkan informasi dengan cepat, murah dan menjangkau wilayah yang sangat luas. Pemanfaatan Internet tidak hanya membawa dampak positif, tapi juga berdampak negatif terhadap kehidupan manusia sehari-hari dalam menjalankan aktifitasnya (Sofana \& Cisco, 2011). Perkembangan teknologi internet yang sangat cepat dan mudahnya cara menggunakannya, memungkinkan siapa saja dapat menggunakan internet. Secara sederhana internet diidefinisikan sebagai jaringan global yang mengkoneksikan jutaan komputer (Witcher 2020)

Apabila dilihat dari karakter masyarakat Indonesia yang sosial, senang berbagi, hobi eksis condong ke narsis, dan tidak begitu concern dengan isu privasi, maka media sosial menjadi medium komunikasi yang sangat representatif. Media sosial memberikan kebebasan kepada penggunanya untuk mem-posting dan membagikan hal yang diinginkan oleh penggunanya. Beragam aplikasi media sosial yang banyak digemari pada setiap aplikasi memiliki fasilitas dan kriteria yang berbeda-beda. Misalnya Instagram yang dibuat untuk berbagi foto dan video yang kemudian membagikannya kepada pengikutnya (followers) Instagram merupakan salah satu aplikasi media sosial yang sedang populer di kalangan masyarakat khususnya remaja untuk berbagi foto atau video bahkan hal pribadi sekalipun (Dewa and Safitri 2021)

Tiktok merupakan aplikasi yang sangat bertolak belakang, karena memiliki tujuan penggunaan yang berbeda. Menurut Didit Putra Erlangga Rahardjo selaku manajer media sosial Kompas Media Nusantara yang membandingkan kedua aplikasi tersebut dalam artikel Kompas berjudul “Video Tiktok Malah Populer di Instagram, Mengapa?”, pada Instagram, pengguna cenderung mengunggah foto atau video pilihan terbaik untuk menjaga estetika profil. Sedangkan di Tiktok, pengguna akan lebih fokus mengunggah konten video yang dibuat secara singkat dan menghibur.(Ruth and Candraningrum 2020) 


\section{Tinjauan Pustaka}

Setelah datangnya instagram menjadi pemicu banyaknya masyarakat yang beralih ke sosial media dalam melakukan banyak hal, aplikasi yang satu ini juga tidak mau kalah dalam memancing masyarakat dalam melakukan segala kegiatan dengan aplikasi ini, aplikasi yang dimaksud ialah tik-tok. Menurut Xu et al. (2019), video pendek merupakan hal yang sangat diminati di dunia internet dimana video pendek yang dibuat tersebut bisa tersebar dalam waku 5 menit ke seluruh dunia, dan karena kepopularitasan dari pengguna ponsel maka semakin meningkat juga aplikasi tik-tok tersebut. Aplikasi tik-tok merupakan aplikasi yang menyalurkan kreatifitas dari pengguna yang ingin mengembangkan musik video pendek di sosial media. Tiktok sendiri sebenarnya sudah keluar dari September tahun 2016 yang dikenal A.me. nama tik-tok mulai terkenal saat dilakukannya penggantian nama pada pertengahan 2017 dan mulai terkenal tahun 2018 (Xu et al., 2019). Pada tahun 2018 lalu sebenarnya tik-tok sudah mulai viral di Indoesia akan tetapi pada saat itu banyak kreator yang membuat video yang kurang mendidik dan sempat menjadi bahan bullyan netizen sehingga pada saat itu pihak Kementrian Komunikasi dan Informatika (Kominfo) sempat memblokir tik-tok, akan tetapi saat ini dikarenakan pandemi banyak orang yang mulai menghabiskan sisa waktunya di sosial media dan salah satunya melalui aplikasi tik-tok inilah yang membuat tik-tok semakin meningkat penggunanya (Wibowo and Yudi 2021)

Pada penelitian ini yang memfokuskan kepada penguna tiktok mempunyai pandangan yang berbeda-beda dan juga pengalaman lingkungan yang berbeda juga. Tentunya penulis melihat dan berfikir bahwa pelaku komunikasi membentuk atau menyampaikan pesannya kepada komunikan dengan memiliki latar belakang yang berbeda dan juga memiliki usia tertentu hingga gerak territorial (asal daerah) yang nantinya akan menentukan perilaku dalam menggunakan aplikasi tiktok. Maka dari itu penulis melihat pada content creator tiktok apakah mereka bertujuan aktualisasi diri atau hanya mengikuti tren masa kini. Tentunya meneliti hal tersebut akan kesulitan jika tidak menggunakan teori yang tepat. Penulis menggunakan teori atribusi dari kognitif informatif (Tiara Dewi, Muhammad Amir Masruhim 2016) 
Tiktok saat ini menjadi salah satu

platform media sosial yang digunakan sebagai digital marketing. Melalui tiktok, barang atau produk yang ingin dijual bisa dibagikan melalui beberapa teknik digital marketing. Berdasarkan analisis konten yang telah peneliti lakukan sebanyak 100 konten dalam akun tiktok @jogjafoodhunterofficial ditemukan beberapa teknik digital marketing, yaitu iklan, storytelling, komedi, diskon, testimoni, tagar, tanya jawab, promo, cashback, audio musik, dan feedback. Iklan merupakan salah satu teknik promosi yang biasanya digunakan untuk mengarahkan komunikasi yang bersifat persuasif pada konsumen sasaran dan bentuk penyajiannya bersifat non-personal (Saladin, D., \& Oesman, Y., 2002). Teknik iklan menjadi salah satu teknik yang digunakan

oleh akun tiktok

@jogjafoodhunterofficial dalam mengelola konten digital marketingnya, ha ini dapat dilihat pada Gambar 2. Teknik ini juga ditemukan dalam penelitian relevan yang dilakukan oleh Indrawati dkk., (2017) (Hilal Ramadhan et al. 2021)

Penelitian ini menggunakan pendekatan kualitatif yang bertujuan untuk mendapatkan pemahaman yang bersifat umum terhadap kenyataan social yang didapatkan dari perpekstif partisipan. Pemahaman ini tidak ditentukan terlebih dahulu, tetapi didapatkan setelah melakukan analisis terhadap kenyataan sosial yang menjadi fokus penelitian (Fauziah 2019)

video yang dapat menambah kreativitas, membuat lpsync maupun membuat video tantangan yang dapat menumbuhkan Kepercayaan Diri nya yang masuk pada tahap perkembangan diri remaja. Berdasarkan hasil pengamatan fenomena-fenomena yang terjadi saat ini dengan adanya media sosial dapat membuat seseorang untuk menghilangkan lelah serta mengusir kebosanannya. Salah satu yang media sosial yang sedang diminati oleh remaja saat ini adalah TikTok. Media sosial TikTok ini merupakan media audio visual, dapat didengarkan juga dapat dilihat. Banyak pengguna media sosial TikTok dari kalangan remaja. Para remaja sangat menyukai media sosial ini karena dapat menghibur dan mengisi waktu luang mereka. (Adawiyah 2020) 


\section{Metode Penelitian}

Pada penelitian ini menggunakan metode meta analisis. Secara sederhana, penelitian meta analisis merupakan analisis atas analisis, atau dengan arti lain meta analisis dapat dilakukan analisis secara komperhensif terhadap beberapa analisis dari berbagai hasil penelitian mengenai topik yang telah dipilih. Sebagai penelitian, meta analisis adalah kajian dari beberapa hasil penelitian dalam masalah yang sejenis (Hidayat, 2018).

Jadi kita bisa melihat siapa saja akun tiktok dengan followers terbanyak serta banyaknya viewsnya, jadi disini terdapat 5 artis dengan followers terbanyak jadi Tidak hanya bermanfaat sebagai sumber informasi, aplikasi ini juga bisa menjadi media penghibur karena beberapa responden menganggap bahwa konten yang ada di TIKTOK menghibur. Selain itu, pada responden juga mengatakan bahwa selama ia menggunakan aplikasi TIKTOK, responden tersebut semakin giat untuk melatih kemampuan editingnya agar dapat menghasilkan konten yang menarik.(Bulele and Wibowo 2020)

Meluasnya penggunaan media sosial Tiktok Media telah memunculkan fenomena baru yang digunakan oleh perusahaan atau individu untuk berinteraksi dan berkomunikasi. Kondisi ini dimanfaatkan untuk mendapatkan followers dengan melakukan inovasi, pemasaran dan komunikasi secara online. Ada beberapa kategori pengguna akun media sosial Tiktok :

1. Kategori pribadi, misalnya: Artis, Tokoh, Pejabat Publik, Selebriti, Pekerja Profesional dan sebagainya.

2. Kategori organisasi, misalnya: Komunitas, Partai Politik, LSM (Organisasi NonPemerintah), NPO (Organisasi Nirlaba)

3. Kategori perusahaan misalnya: segala bentuk perusahaan yang bertujuan untuk menghasilkan keuntungan. Jenis penelitian eksplorasi ini akan 


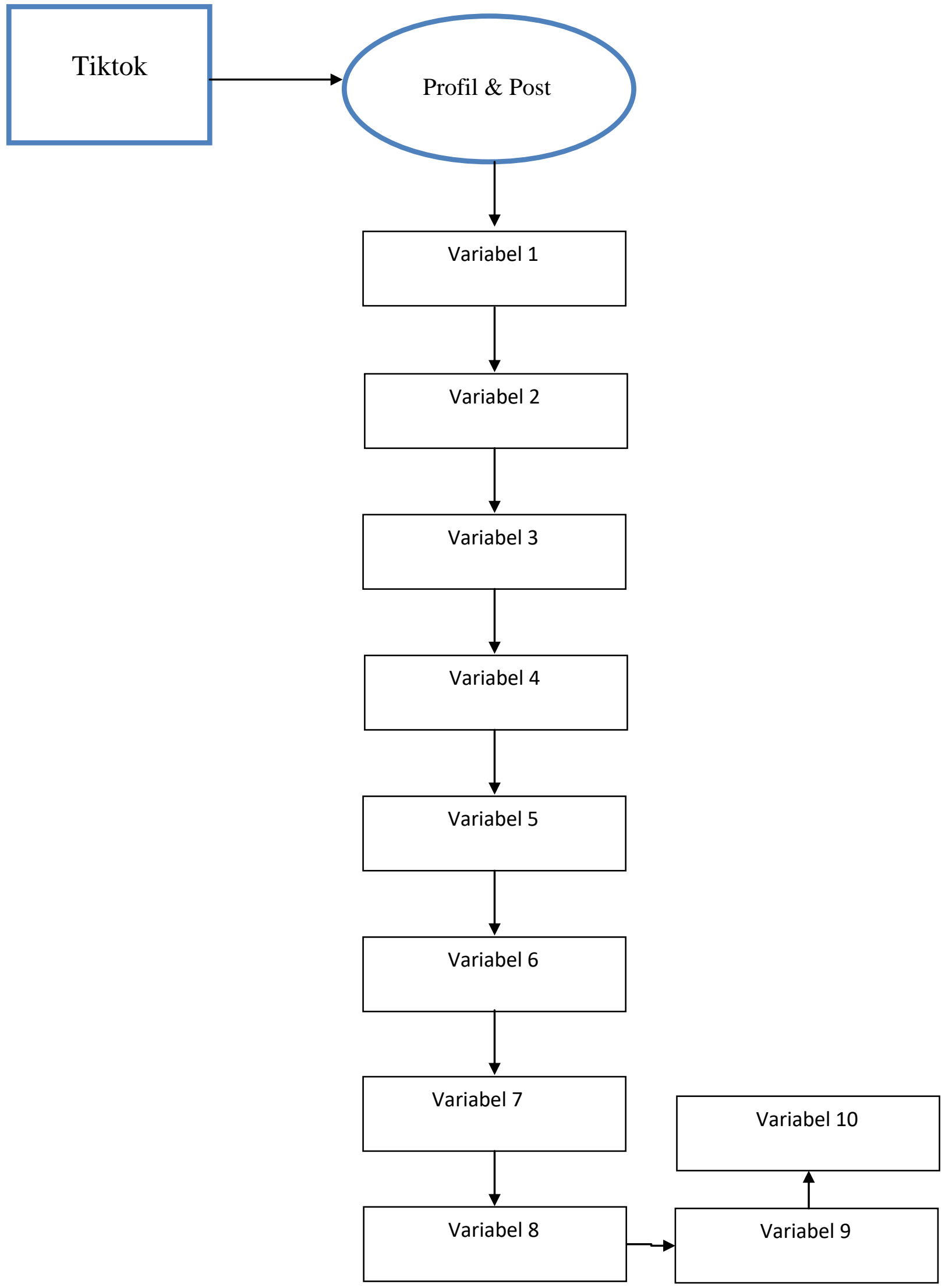

Gambar1. Analisis Nilai rata-rata 


\section{Menghitung Nilai Rata-Rata Variabel 5 Artis dengan followers terbanyak di}

\section{Indonesia.}

Pada langkah ini, peneliti menghitung nilai views to likes ratio tiktok . Variabel merupakan sesuatu yang memiliki nilai bervariasi dimana nilai tersebut dapat dijadikan sebagai dasar untuk empat data yang berbeda seperti rasio, skala, ordinal, nominal dan internal, Untuk menghitung nilai rata-rata dari variabel video comments dan variabel video views to likes yaitu dengan cara mengambil minimal 10 postingan kemudian di hitung sehingga menemukan nilai rata-rata dari masing-masing variabel,(I Putu Hendika Permana and Ni Putu Suci Meinarni 2021) pada gambar diatas

\section{Menghitung Nilai Kredibilitas Rasio}

Untuk menghitung nilai kredibilitas dari views to likes ratio tiktok, peneliti bisa menggunakan cara membagi nilai variabel pertama dengan nilai variabel kedua. Jika video comments memiliki nilai 100 dan video views memiliki nilai 300, maka cara menghitungnya yaitu $100: 300=0,3$. Dengan begitu nilai dari video comments to video views ratio adalah 0,3 .

\section{Menentukan Peringkat Pada Akun TikTok}

Pada langkah terakhir yang dilakukan pada penelitian ini yaitu menentukan peringkat

pada masing-masing rasio yang terdapat pada objek. Pada penentuan peringkat perlu melihat karakteristik dari rasio yang di teliti. Jika karakteristik rasio merupakan rendah, maka objek yang memiliki nilai terendah akan mendapatkan angka 5 dan objek yang memiliki nilai tertinggi akan mendapatkan angka 1. Namun jika rasio memiliki karakteritik tinggi maka objek yang mendapatkan nilai tinggi akan mendapatkan angka 5 dan objek yang mendapatkan nilai terendah akan mendapatkan angka 1. Setelah mendapatkan hasil kredibilitas ratio maka dapat disimpulkan objek yang mana mendapatkan peringkat 1 sampai dengan peringkat 5 . 


\section{Hasil dan Pebahasan}

\section{Akun Tiktok artis dengan views dan likes terbanyak}

1. Akun Tiktok Sandys.ss

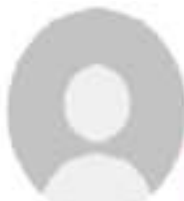

\section{sandys.ss}

ss

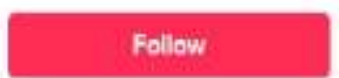

290 Following

15.2M Followets $\quad 465.4 \mathrm{M}$ Likes

16 "sandys.ss"

Suggested accounts

\section{Akun Tiktok Cahyanirynn}

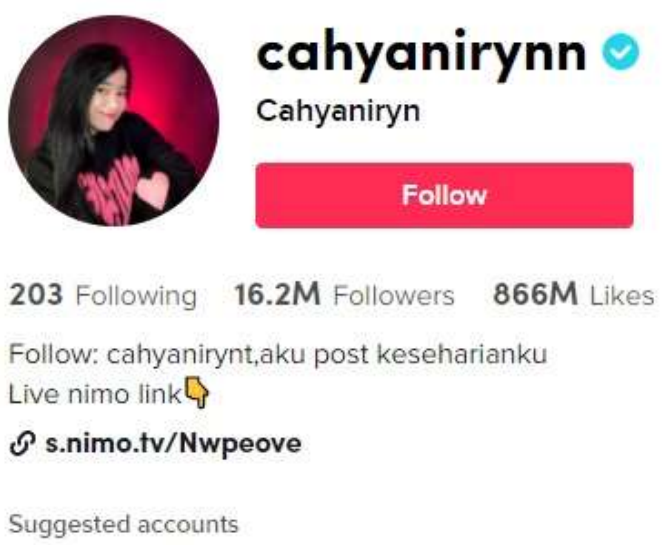

Gambar 2. Akun Tiktok cahyanirynn

Sumber : https://www.tiktok.com/@cahyanirynn (akses pada 15-10-2021) 


\section{Akun Tiktok RiaRicis}

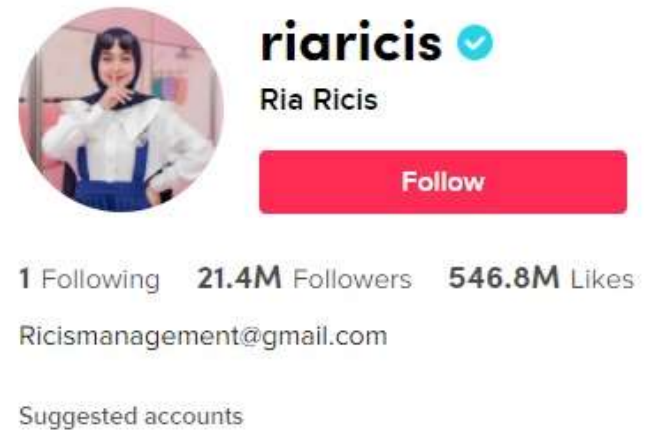

See ail

Gambar 3. Akun Tiktok riaricis

Sumber : https://www.tiktok.com/@ riaricis (akses pada 15-10-2021)

\section{Akun Tiktok JharnaBhagwani}

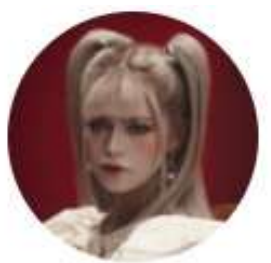

\section{jharnabhagwani}

jharna bhagwani

\section{Ikuti}

67 Mengikuti $\quad 10.2 \mathrm{M}$ Pengikut $\quad 145.8 \mathrm{M}$ Suka

My first single "Tell Me" is out on all platforms

Insta: jharnabhagwani

$\mathcal{O}$ bfan.link/jharna-tellme

Saran akun

Lihat semua

Gambar 4. Akun Tiktok jharnabhagwani

Sumber : https://www.tiktok.com/@jharnabhagwani (akses pada 15-10-2021) 


\title{
5. Akun Tiktok Saalhaerid
}

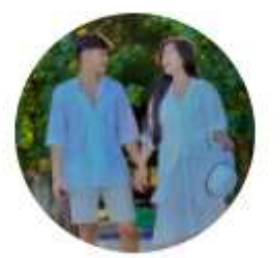

\section{saalhaerid}

Said

\author{
Follow
}

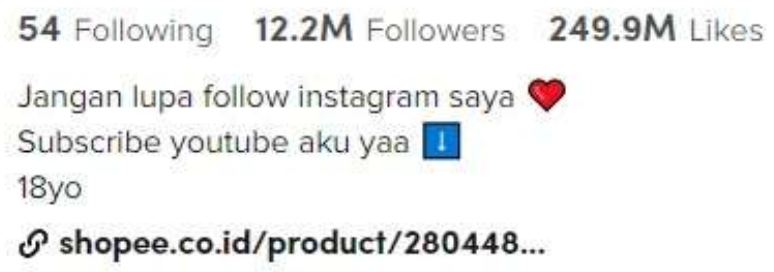

Dari kelima akun TikTok Dengan Follwers, peneliti menemukan nilai dari masing-masing variabel yang ada untuk menghitung rasio Video Comments to Video Views dari setiap akun. Pada akun TikTok terdapat 2 variabel, diantaranya yaitu

- Video Views

- Video Likes

Tabel 1. Analisa Nilai Rata-Rata Nilai Variabel Views dan Video Likes Akun TikTok Sandys.ss

\begin{tabular}{|c|c|c|}
\hline No. & Video Views & Video Like \\
\hline 1 & 352.600 & 76.000 \\
\hline 2 & 285.800 & 52.100 \\
\hline 3 & 504.600 & 80.400 \\
\hline 4 & 409.900 & 63.300 \\
\hline 5 & 140.000 & 21.000 \\
\hline 6 & 114.700 & 16.400 \\
\hline 7 & 267.600 & 44.700 \\
\hline 8 & 826.000 & 105.900 \\
\hline 9 & 737.500 & 51.500 \\
\hline 10 & 409.000 & 20.500 \\
\hline Total & $\mathbf{4 0 4 . 7 7 0}$ & $\mathbf{5 3 . 1 8 0}$ \\
\hline
\end{tabular}


Sumber : Pengolah Data Excel

Tabel 2. Analisa Nilai Rata-Rata Nilai Variabel Views dan Video Likes Akun TikTok Cahyanirynn

\begin{tabular}{|c|c|c|}
\hline No & Video Views & Video Likes \\
\hline 1 & 239.600 & 46.300 \\
\hline 2 & 390.300 & 61.300 \\
\hline 3 & 446.000 & 70.700 \\
\hline 4 & 616.700 & 104.900 \\
\hline 5 & 318.600 & 46.000 \\
\hline 6 & 824.600 & 131.400 \\
\hline 7 & 594.600 & 95.200 \\
\hline 8 & 870.600 & 123.700 \\
\hline 9 & 276.700 & 40.000 \\
\hline 10 & 1.000 .000 & 153.400 \\
\hline Total & $\mathbf{5 5 7 . 7 7 0}$ & $\mathbf{8 7 . 2 9 0}$ \\
\hline
\end{tabular}

Sumber : Pengolah Data Excel

Tabel 3. Analisa Nilai Rata-Rata Nilai Variabel Views dan Video Likes Akun TikTok RiaRicis

\begin{tabular}{|c|c|c|}
\hline No & Video views & Video Likes \\
\hline 1 & 331.300 & 39.600 \\
\hline 2 & 11.600 .000 & 1.200 .000 \\
\hline 3 & 2.100 .000 & 23.200 \\
\hline 4 & 6.500 .000 & 893.100 \\
\hline 5 & 12.600 .000 & 1.500 .000 \\
\hline 6 & 12.800 .000 & 1.400 .000 \\
\hline 7 & 14.700 .000 & 1.900 .000 \\
\hline 8 & 420.000 & 237.600 \\
\hline 9 & 6.200 .000 & 639.000 \\
\hline 10 & 6.500 .000 & 552.100 \\
\hline Total & 7.375 .130 & 838.460 \\
\hline
\end{tabular}

Sumber : Pengolah Data Excel 
Tabel 4. Analisa Nilai Rata-Rata Nilai Variabel Views dan Video Likes Akun TikTok JharnaBhagwani

\begin{tabular}{|c|c|c|}
\hline No & Video Views & Video Likes \\
\hline 1 & 3.900 .000 & 727.600 \\
\hline 2 & 1.000 .000 & 108.100 \\
\hline 3 & 1.500 .000 & 201.100 \\
\hline 4 & 8.500 .000 & 1.600 .000 \\
\hline 5 & 535.800 & 68.500 \\
\hline 6 & 829.300 & 81.900 \\
\hline 7 & 248.000 & 20.900 \\
\hline 8 & 920.800 & 196.500 \\
\hline 9 & 1.200 .000 & 142.300 \\
\hline 10 & 405.700 & 22.100 \\
\hline Total & 1.903 .960 & 316.900 \\
\hline
\end{tabular}

Sumber : Pengolah Data Excel

Tabel 5. Analisa Nilai Rata-Rata Nilai Variabel Views dan Video Likes Akun TikTok Saalhaerid

\begin{tabular}{|c|c|c|}
\hline No & Video Views & Video Likes \\
\hline 1 & 3.200 .000 & 197.900 \\
\hline 2 & 40.300 .000 & 1.800 .000 \\
\hline 3 & 267.100 & 58.000 \\
\hline 4 & 727.900 & 122.200 \\
\hline 5 & 1.200 .000 & 125.900 \\
\hline 6 & 293.000 & 54.200 \\
\hline 7 & 1.800 .000 & 267.700 \\
\hline 8 & 641.400 & 83.300 \\
\hline 9 & 568.100 & 42.900 \\
\hline 10 & 1.400 .000 & 150.900 \\
\hline Total & $\mathbf{5 . 0 3 9 . 7 5 0}$ & $\mathbf{2 9 0 . 3 0 0}$ \\
\hline
\end{tabular}

Sumber : Pengolah Data Excel 
Setelah menghitung nilai rata-rata tersebut, maka akan menemukan hasil akhir nilai rata-rata dari variabel video views dan video likes

Tabel 6. Nilai Variabel Pada Akun TikTok artis followers terbanyak

\begin{tabular}{|c|c|c|c|c|c|}
\hline Variabel & Sandys.ss & Cahyanirynn & RiaRicis & JharnaBhagwani & Saalhaerid \\
\hline Video Views & 404.770 & 557.770 & 7.375 .130 & 1.903 .960 & 5.039 .750 \\
\hline Video Likes & 53.180 & 87.290 & 838.460 & 316.900 & 290.300 \\
\hline
\end{tabular}

Pada akun TikTok terdapat 5 rasio yang relevan digunakan untuk mengukur kredibilitas pada masing-masing akun. Namun pada penelitian kali ini hanya berfokus untuk menghitung Video Views to Video likes Ratio. Untuk menghitung kredibilitas dari masing-masing akun TikTok setiap artis dengan follwers terbanayl, peneliti menghitung dengan cara : variabel 1 akan dibagi dengan variabel 2, sehingga ditemukan hasil analisisa dari rasio tersebut.

Tabel 7. Hasil Perhitungan Rasio Akun TikTok

\begin{tabular}{|c|c|c|c|c|c|c|}
\hline Ratio & Sandys.ss & Cahyanirynn & RiaRicis & JharnaBhagwani & Saalhaerid & Karateristik \\
\hline Video Views to Video Likes Ratio Tiktok & 7,611320045 & 6,389849926 & 8,796042745 & 6,008078258 & 17,36048915 & Tinggi \\
\hline
\end{tabular}

Sumber : Pengolah Data Excel

Video Views to Video Likes Ratio memiliki karakteristik yang tinggi, artinya semakin tinggi nilai yang dihasilkan maka semakin baik kredibilitas dari performa akun tersebut. Untuk memberikan peringkat pada masing-masing akun artis tersebut, peneliti memberikan angka 5 kepada artis yang mendapatkan nilai tertinggi dan angka 1 untuk artis tiktok yang mendapatkan nilai terendah. Berikut merupakan tabel urutan nilai yang dihasilkan oleh masing-masing artis tiktok 
Tabel 8. Nilai Rasio Akun TikTok Artis Terbanyak

\begin{tabular}{|c|c|c|c|c|}
\hline Sandys.ss & Cahyanirynn & RiaRicis & JharnaBhagwani & Saalhaerid \\
\hline 3 & 4 & 2 & 5 & 1 \\
\hline
\end{tabular}

Sumber : Pengolah Data Excel

\section{Kesimpulan Dari Analisis Views to Video Likes Ratio Tiktok :}

- Pertama Account saalhaerid

- Kedua Account RiaRicis

- Ketiga Account Sandys.ss

- Keempat Account Cahyanirynm

- Kelima JharnaBhagwani 


\section{Daftar Pustaka}

Adawiyah, Dwi Putri Robiatul. 2020. "Pengaruh Penggunaan Aplikasi TikTok Terhadap Kepercayaan Diri Remaja Di Kabupaten Sampang.” Jurnal Komunikasi 14 (2): 135-48.

https://doi.org/10.21107/ilkom.v14i2.7504.

Bulele, Yohana Noni, and Tony Wibowo. 2020. "Analisis Fenomena Sosial Media Dan Kaum Milenial: Studi Kasus Tiktok.” Conference on Business, Social Sciences and Innovation Technology 1 (1): 56572. http://journal.uib.ac.id/index.php/cbssit.

Dewa, Chriswardana Bayu, and Lina Ayu Safitri. 2021. "Pemanfaatan Media Sosial Tiktok Sebagai Media Promosi Industri Kuliner Di Yogyakarta Pada Masa Pandemi Covid-19 (Studi Kasus Akun TikTok Javafoodie)." Khasanah Ilmu - Jurnal Pariwisata Dan Budaya 12 (1): 65-71. https://doi.org/10.31294/khi.v12i1.10132.

Fauziah, Yuliani Resti. 2019. “Konsep Diri Remaja Pengguna Aplikasi Tik Tok Di Kota Bandung.” Jurnal Ilmu Komunikasi, no. 112: 1-2.

Hilal Ramadhan, Ilham, Ryan Priatama, Awanis Akalili, and Febriansyah Kulau. 2021. "Analisis Teknik Digital Marketing Pada Aplikasi Tiktok (Studi Kasus Akun TikTok @jogjafoodhunterofficial) Analysis of Digital Marketing Techniques in Tiktok Aplication (Case Study of @jogjafoodhunterofficial).” Online) Socia: Jurnal Ilmu-Ilmu Sosial 18 (1): 49-60.

I Putu Hendika Permana, and Ni Putu Suci Meinarni. 2021. "Ratio Analysis on Tiktok (Social Media) for Qualitative Research Using Explorative Methods.” Jurnal Ekonomi \& Bisnis JAGADITHA 8 (1): 3038. https://doi.org/10.22225/jj.8.1.2944.30-38.

Ruth, Debra, and Diah Ayu Candraningrum. 2020. "Pengaruh Motif Penggunaan Media Baru Tiktok Terhadap Personal Branding Generasi Milenial Di Instagram.” Koneksi 4 (2): 207. https://doi.org/10.24912/kn.v4i2.8093.

Tiara Dewi, Muhammad Amir Masruhim, Riski Sulistiarini. 2016. “済無No Title No Title No Title.” Laboratorium Penelitian Dan Pengembangan FARMAKA TROPIS Fakultas Farmasi Universitas Mualawarman, Samarinda, Kalimantan Timur, no. April: 5-24.

Wibowo, Tony, and Yudi. 2021. "Studi Penetrasi Aplikasi Media Sosial Tik-Tok Sebagai Media Pemasaran Digital : Studi Kasus Kota Batam.” Conference on Business, Social Sciences and Technology 1 (1): 662-69. https://journal.uib.ac.id/index.php/conescintech.

Witcher, Barry J. 2020. "Pengaruh Aplikasi Tik Tok Terhadap Ekspresi Komunikasi Mahasiswa Universitas Islam Negeri (Uin) Sunan Ampel Surabaya Tahun.” Incare: International Journal of Educational Resources 01 (02): 155. 